\title{
PHYSICAL PROPERTIES OF SOME MECHANICAL VIBRATORS AND THEIR CLINICAL RELEVANCE
}

\author{
K. E. BRINKWORTH, B.Sc. (Physiotherapy) (Witwatersrand)
}

Die korrekle tipe vibrator vir skeletspiersametrekking word bespreek. Dis belangrik dat die vibrasiefrekwens korrek is vir terapie. Die frekwens van drie vibrators wat dikwels in die praktyk gebruik word, word bepaal. Die gegewens word vergelyk met die wat reeds in die literatuur beskryf is.

The success of the use of mechanical vibration in order to elicit a contraction in skeletal muscle is dependent on a few major factors:

1. An intact nerve supply to the muscle. (Bishop, 1974).

2. The site of stimulation. (Stillman, 1970).

3. The duration of stimulation. (Marsden et al. 1969).

4. The amplitude of vibratory stimulus. (Matthews 1967).

5. The frequency of vibratory stimulus. (Bishop, 1975).

Recent work in this field deals with all these factors (1-5), but in procuring a vibrator for therapeutic use one is concerned specifically with the frequency and amplitude of vibration produced by the instrument.

Therefore the following data is essential:

1. Therapeutic frequencies must range from $100 \mathrm{~Hz}$ to $200 \mathrm{~Hz}$. (Bishop, 1975).

2. The amplitude required for therapeutic effect varies with the depth of the muscle, pressure of application and the size of the limb. The literature so far has not specifically stated or recommended definite amplitudes, but amplitudes of approximately 1 to 4 millimetres appear to be used experimentally. (Matthews, 1967; Brinkworth, 1975).

Three vibrators which were commercially available and most commonly used by therapists in this country were examined using a stroboscope (matching the rate of flashing light with frequency of vibration) and readings were checked on an oscilloscope (Type 541A). The investigation revealed the following:

1. The battery operated vibrator, sold as the "Stimulant" and used by Professor Rood when lecturing here in 1969, emits a large range of frequencies. These frequencies were not clear on oscilloscope (as many were produced), but basically two components of $330 \mathrm{~Hz}$ and $660 \mathrm{~Hz}$ emerged.

2. Of the vibrators which operate off the mains current (those which are plugged in), the Wahl and the Pifco are the two most readily available commercially.
(a) The Wahl emits a vibratory frequency of $100 \mathrm{~Hz}$ and the amplitude of vibration was estimated as being more than $3 \mathrm{~mm}$.
(b) The Pifco also produces a vibratory frequency of $100 \mathrm{~Hz}$ and the amplitude was estimated at 2 to $3 \mathrm{~mm}$.

NOTE: The frequency of vibration of the instrument varies slightly with the frequency of the exciting force. (This is reported by E.S.COM. to be minimal).

The figure 50 cycles or $50 \mathrm{~Hz}$ on the vibrator means that they should be operated off a current alternating at 50 cycles per second. This is the 'exciting force' of the vibratory mechanism which is triggered by an electromagnet. Induction of the magnet occurs with the change in direction of the current. This happens twice in each cycle. Therefore within the time period of one second containing 50 cycles, there will ie an induction rate of $100 / \mathrm{sec}$ and hence vibration of $100 \mathrm{~Hz}$.

Table I clarifies these findings:

\section{TABLE I}

\begin{tabular}{ccc}
\hline Vibrator & Frequency & Amplitude \\
\hline Stimulant & $330-660 \mathrm{~Hz}$ & not assessed \\
Wahl & $100 \mathrm{~Hz}$ & $>3 \mathrm{mms}$ \\
Pifco & $100 \mathrm{~Hz}$ & $2-3 \mathrm{mms}$ \\
\hline
\end{tabular}

\section{Conclusion}

Considering the recommended frequency range of 100 to $200 \mathrm{~Hz}$ in experimental situations, and with the information submitted above, it is understandable that physiotherapists have obtained disappointing responses with the battery operated vibrator, whereas more encouraging reports tend to be received from therapists using the other vibrators described.

\section{Acknowledgements}

I would like to thank Mr J. L. Crawford (Dept. of Physics, University of the Witwatersrand) and Dr D. G. Schuster (Dept. of Physics, University of Natal) for their assistance in investigating vibratory frequencies.

\section{References}

1. Bishop, B. (1974): Neurophysiology of Motor Responses evoked by Vibratory Stimulation. Physical Therapy 54, 1273-1281.

2. Bishop, B. (1975): Possible Applications of Vibration in the Treatment of Motor Dysfunctions. Physical Therapy 55, 139-143.

3. Brinkworth, K. E. (1975): The Vibrator - Therapeutic Tool or Academic Toy? S.A.J. Physiotherapy 31, 3, 11-13.

4. Marsden, C. D., Meadows, J. C. and Hodgson, H. J. F. (1969): Observations of the Reflex Response to Muscle Vibration in Man and its Voluntary Control. Brain 92, 829-864.

5. Matthews, P. B. C. (1967): The Reflex Excitation of Soleus Muscle of the Decerebrate Cat caused by Vibration Applied to its Tendon. J. Physiol. 192, 773-800.

6. Stillman, B. C. (1970): Vibratory Motor Stimulation - a Preliminary Report. Australian J. Physiotherapy 16, 118-123. 